\title{
Eosinophilia in critically ill COVID-19 patients: a French monocenter retrospective study
}

\author{
Megan Fraissé, Elsa Logre, Hervé Mentec, Radj Cally, Gaëtan Plantefève and Damien Contou* (i)
}

\section{Introduction}

As reported in bacterial sepsis [1], the early phase of SARS-CoV-2 infection seems to be accompanied by eosinopenia [2-4]. Conversely, our team noticed that several of our critically ill COVID-19 patients developed unexpected and unexplained eosinophilia during their ICU stay. Indeed, as white blood cells count is performed almost daily, monitoring and studying eosinophil course is simple in the ICU setting. To our knowledge, no study has focused on eosinophilia in COVID-19 although eosinophil recovery seven days after initial eosinopenia seems to be associated with a better outcome [3].

We aimed to assess the incidence and to describe eosinophilia in critically ill COVID-19 patients, as well as to compare the outcome between patients developing or not eosinophilia during their ICU stay.

\section{Methods}

We retrospectively reviewed all daily white blood cells counts performed in adult COVID-19 patients (RTPCR positive for SARS-CoV-2) admitted to our 40-bed COVID-19 ICU between March 6 and July 30, 2020. Eosinophilia was defined by an eosinophil count higher than $500 / \mathrm{mm}^{3}$ and was considered as severe when exceeding $1500 / \mathrm{mm}^{3}$. Eosinopenia was defined by an eosinophil count lower than $40 / \mathrm{mm}^{3}$.

*Correspondence: damien.contou@ch-argenteuil.fr Service de Réanimation Polyvalente, Centre Hospitalier Victor Dupouy, 69, rue du Lieutenant-Colonel Prud'hon, 95100 Argenteuil, France

\section{Results}

During the study period, 99 patients were admitted for acute respiratory failure related to SARS-CoV-2 pneumonia. After excluding 21 patients transferred to another ICU, 78 patients remained in the analysis. Among them, $69(88 \%)$ had eosinopenia at ICU admission and 26 (33\%, 95\% confidence interval 23-45\%) developed eosinophilia during ICU stay.

Among the 26 patients who developed eosinophilia (Table 1), 22 (85\%) had eosinopenia at ICU admission. Eosinophilia occurred 19 [13-28] days after ICU admission and lasted 5 [3-12] days. Median eosinophil count was $900[678-1350] / \mathrm{mm}^{3}$. Six patients (23\%) developed severe eosinophilia. Seven patients $(29 \%)$ had a biphasic eosinophilia. Ten (38\%) patients were treated with a $\beta$-lactam antibiotic when eosinophilia occurred. Eleven (42\%) patients had at least once a temperature $>38.3{ }^{\circ} \mathrm{C}$ and $2(8 \%)$ had an erythematous skin rash during the eosinophilia period, respectively.

Comparison between patients with and without eosinophilia during ICU stay is detailed in Table 2.

By using a Cox model with time-varying covariate and after adjustment for SAPSII, age and administration of glucocorticoids, eosinophilia was associated with a decreased ICU mortality (HR $=0.44,95 \%$ CI $0.23-0.85$, $p=0.014)$.

\section{Discussion}

Despite an $88 \%$ rate of eosinopenia at ICU admission, we report that one-third of our critically ill COVID-19 patients developed an unexpected late-onset and prolonged ICU-acquired eosinophilia which was severe in original author(s) and the source, provide a link to the Creative Commons licence, and indicate if changes were made. The images or other third party material in this article are included in the article's Creative Commons licence, unless indicated otherwise in a credit line to the material. If material is not included in the article's Creative Commons licence and your intended use is not permitted by statutory regulation or exceeds the permitted use, you will need to obtain permission directly from the copyright holder. To view a copy of this licence, visit http://creativecommons.org/licenses/by/4.0/. The Creative Commons Public Domain Dedication waiver (http://creativeco mmons.org/publicdomain/zero/1.0/) applies to the data made available in this article, unless otherwise stated in a credit line to the data. 
Table 1 Description of eosinophilia $\left(>500 / \mathrm{mm}^{3}\right.$ ) in 26 critically ill patients with SARS-CoV-2 pneumonia

\begin{tabular}{|c|c|}
\hline & $\begin{array}{l}\text { Patients } \\
\text { with eosinophilia } \\
\text { during ICU stay } N=26\end{array}$ \\
\hline \multicolumn{2}{|l|}{ Eosinophil count at ICU admission } \\
\hline Median eosinophils count (cell/mm³) & $5[0-20]$ \\
\hline Eosinophilia $\left(>500 / \mathrm{mm}^{3}\right)$ & $1(4)$ \\
\hline Eosinopenia $\left(<40 / \mathrm{mm}^{3}\right)$ & $22(85)$ \\
\hline No eosinophil & $13(50)$ \\
\hline Normal eosinophil count & $3(11)$ \\
\hline \multicolumn{2}{|l|}{ Eosinophilia during ICU stay } \\
\hline Days between ICU admission and eosinophilia & 19 [13-28] \\
\hline Days between disease onset and eosinophilia & 30 [23-38] \\
\hline Days between disease onset and pic of eosinophilia & $31[25-42]$ \\
\hline Median eosinophil count (cells/mm³) & 900 [678-1350] \\
\hline Severe eosinophilia $\left(>1500 / \mathrm{mm}^{3}\right)$ & $6(23)$ \\
\hline Total duration of eosinophilia (days) & $5[3-12]$ \\
\hline Biphasic eosinophilia & $7(27)$ \\
\hline Administration of $\beta$-lactam antibiotics during eosinophilia period & $10(38)$ \\
\hline Temperature $>38.3^{\circ} \mathrm{C}$ at least once during eosinophilia period & $11(42)$ \\
\hline Erythematous skin rash during the eosinophilia period & $2(8)$ \\
\hline Treatment with ivermectin for eosinophilia & $3(12)$ \\
\hline
\end{tabular}

Continuous variables are reported as median [Interquartile range] and categorical variables are reported as numbers (percentage)

almost one quarter of them. Such a high rate of eosinophilia is uncommon in non-COVID-19 critically ill patients and has never been documented in other viral infection such as influenza. A clear explanation for eosinophilia was not retrieved in our patients even if a drug-induced eosinophilia could not be formally ruled out. Some patients with severe eosinophilia were even empirically treated with ivermectin for a hypothetic helminthiasis-related eosinophilia. Given that eosinophilia was a late-onset event in the course of ICU stay, its positive impact on survival is difficult to interpret, patients developing eosinophilia being exposed to a survival bias.
Considering the absence of a clear explanation for the high rate of eosinophilia observed in our patients, we can legitimately hypothesize that SARS-CoV-2 was directly or indirectly responsible for eosinophilia, as a consequence of infection or recovery. The late occurrence of eosinophilia is consistent with the prolonged SARSCoV-2 RNAaemia reported in critically ill patients [5]. Whether eosinophilia is a marker of an excessive immune recovery or a dysregulated immune response during the cytokine storm [6] induced by the infection is unknown.

Even if our study suffers from several limitations, our findings emphasize the underestimated and understudied role of eosinophils in COVID-19. Further, larger studies are needed to overcome these limitations. 
Table 2 Comparison between 78 critically ill patients with SARS-CoV-2 pneumonia developing $(n=26)$ or not $(n=52)$ eosinophilia (eosinophils count $>500 \mathrm{~mm}^{3}$ ) during ICU stay

\begin{tabular}{|c|c|c|c|c|}
\hline & All patients $N=78$ & $\begin{array}{l}\text { Patients } \\
\text { with eosinophilia } N=26\end{array}$ & $\begin{array}{l}\text { Patients } \\
\text { without eosinophilia } N=52\end{array}$ & $p$ \\
\hline \multicolumn{5}{|l|}{ Patients characteristics and ICU scores } \\
\hline Male sex & $62(79)$ & $22(85)$ & $40(77)$ & 0.62 \\
\hline Age, years & $62[54-70]$ & $62[55-70]$ & $62[54-70]$ & 0.84 \\
\hline SOFA & $4[3-7]$ & $4[3-7]$ & $4[3-8]$ & 0.44 \\
\hline SAPS $\|$ & $33[22-44]$ & $34[28-38]$ & $31[19-44]$ & 0.72 \\
\hline Days between disease onset and ICU admission & $8[7-12]$ & $10[7-13]$ & $8[7-12]$ & 0.28 \\
\hline \multicolumn{5}{|l|}{ Main comorbidities, n (\%) } \\
\hline Obesity (body mass index $\geq 30 \mathrm{~kg} / \mathrm{m}^{2}$ ) & $36(46)$ & $9(36)$ & $27(53)$ & 0.25 \\
\hline Arterial hypertension & $51(65)$ & $13(50)$ & $38(73)$ & 0.08 \\
\hline Diabetes mellitus & $33(42)$ & $12(46)$ & $21(40)$ & 0.81 \\
\hline Ischemic cardiopathy & $8(10)$ & $3(12)$ & $5(10)$ & 1.00 \\
\hline Cerebro-vascular diseases & $7(9)$ & $4(15)$ & $3(6)$ & 0.21 \\
\hline Venous thrombo-embolism & $5(6)$ & $2(8)$ & $3(6)$ & 1.00 \\
\hline Chronic respiratory diseases & $18(23)$ & $6(24)$ & $12(24)$ & 1.00 \\
\hline Chronic renal failure & $7(9)$ & $2(8)$ & $5(10)$ & 1.00 \\
\hline Recent cancer or hemopathy & $3(4)$ & $1(4)$ & $2(4)$ & 1.00 \\
\hline ACE or ARB & $35(45)$ & $11(42)$ & $24(47)$ & 0.88 \\
\hline \multicolumn{5}{|l|}{ Biological data at ICU admission } \\
\hline Median eosinophils count (cell/mm³) & $0[0-10]$ & $5[0-20]$ & $0[0-10]$ & 0.43 \\
\hline Eosinophilia $\left(>500 / \mathrm{mm}^{3}\right)$ & $1(1)$ & $1(4)$ & $0(0)$ & 0.33 \\
\hline Eosinopenia $\left(<40 / \mathrm{mm}^{3}\right)$ & $69(88)$ & $22(85)$ & $47(90)$ & 0.47 \\
\hline No eosinophils & $47(60)$ & $13(50)$ & $34(65)$ & 0.29 \\
\hline Fibrinogen (g/L) & $8[6-9]$ & $7[6-8]$ & $8[7-9]$ & 0.37 \\
\hline D-dimers $(\mu \mathrm{g} / \mathrm{mL})$ & 2440 [1570-9915] & 2415 [1968-13670] & $2720[1400-7250]$ & 0.36 \\
\hline Prothrombin time (\%) & $85[75-96]$ & $87[80-96]$ & 85 [70-96] & 0.59 \\
\hline Platelets count (G/L) & 225 [164-291] & 209 [190-327] & $226[161-272]$ & 0.34 \\
\hline \multicolumn{5}{|l|}{ Treatment for SARSCoV-2 pneumonia } \\
\hline Glucocorticoids $^{\mathrm{a}}$ & $12(15)$ & $4(15)$ & $8(15)$ & 1.00 \\
\hline Hydroxychloroquine ${ }^{b}$ & $2(3)$ & $1(4)$ & $1(2)$ & 1.00 \\
\hline Azithromycin & 0 & - & - & - \\
\hline Remdesivir & 0 & - & - & - \\
\hline Lopinavir-ritonavir & 0 & - & - & - \\
\hline Tocilizumab & 0 & - & - & - \\
\hline \multicolumn{5}{|l|}{ Outcomes in the ICU } \\
\hline Invasive mechanical ventilation & $68(87)$ & $25(96)$ & $43(83)$ & 0.15 \\
\hline Prone positioning & $48(62)$ & $18(69)$ & $30(58)$ & 0.46 \\
\hline Vasopressor support & $49(63)$ & $19(73)$ & $30(58)$ & 0.28 \\
\hline Acute kidney failure & $55(71)$ & $19(79)$ & $36(69)$ & 0.53 \\
\hline Renal replacement therapy & $24(31)$ & $12(46)$ & $12(23)$ & 0.07 \\
\hline Ventilator-associated pneumonia & $45(58)$ & $19(73)$ & $26(50)$ & 0.09 \\
\hline Thrombotic event during ICU stay & $33(42)$ & $12(48)$ & $21(40)$ & 0.70 \\
\hline Length of ICU stay, days & $16[8-30]$ & $31[23-52]$ & $12[6-21]$ & $<0.001$ \\
\hline ICU mortality & $38(49)$ & $9(35)$ & $29(56)$ & 0.13 \\
\hline Days between ICU admission and death & $13(8-21)$ & $23(18-47)$ & $12(8-16)$ & $<0.001$ \\
\hline
\end{tabular}

Continuous variables are reported as median [Interquartile range] and compared between groups using the Student $t$ test. Categorical variables are reported as numbers and percentages and compared using $x^{2}$ test. A $p$ value $<0.05$ was considered significant

ACE/ARB angiotensin-converting enzyme inhibitors/angiotensin receptor blockers, ICU intensive care unit, SAPS2 simplified acute physiology score, SOFA sepsisrelated organ failure assessment

a In a context of randomized clinical trial $(n=10)$ or as a salvage therapy $(n=2)$

b In a context of randomized clinical trial 


\section{Acknowledgements}

We warmly acknowledge Dr Marie Dubert for statistical analysis and Dr Olivier Pajot for careful data interpretation.

\section{Authors' contributions}

MF and DC are responsible for the conception and design. All the authors were responsible for the data acquisition, analysis and interpretation. DC takes responsibility for the paper as a whole. All authors read and approved the final manuscript.

\section{Funding}

No funding.

\section{Availability of data and materials}

The dataset used and analyzed for the current study is available from the corresponding author on reasonable request.

\section{Ethics approval and consent to participate}

This study was conducted in accordance with the amended Declaration of Helsinki and was approved by the Institutional Review Board (CE 2020-67) of the French Intensive Care Society.

\section{Consent for publication}

Not applicable.

\section{Competing interests}

The authors declare that they have no competing interests.

Received: 19 October 2020 Accepted: 26 October 2020

Published online: 03 November 2020

\section{References}

1. Abidi K, Khoudri I, Belayachi J, Madani N, Zekraoui A, Zeggwagh AA, et al. Eosinopenia is a reliable marker of sepsis on admission to medical intensive care units. Crit Care. 2008;12:R59.

2. Li Q, Ding X, Xia G, Chen H-G, Chen F, Geng Z, et al. Eosinopenia and elevated C-reactive protein facilitate triage of COVID-19 patients in fever clinic: a retrospective case-control study. EClinicalMedicine. 2020;23:100375.

3. Mateos Gonzalez M, Sierra Gonzalo E, Casado Lopez I, Arnalich Fernandez F, Beato Perez JL, Monge Monge D, et al. The prognostic value of eosinophil recovery in COVID-19: a multicentre, retrospective cohort study on patients hospitalised in Spanish hospitals. medRxiv. 2020;2020.08.18.20172874.

4. Du Y, Tu L, Zhu P, Mu M, Wang R, Yang P, et al. Clinical features of 85 fatal cases of COVID-19 from Wuhan. A retrospective observational study. Am J Respir Crit Care Med. 2020;201:1372-9.

5. Buetti N, Wicky PH, Le Hingrat Q, Ruckly S, Mazzuchelli T, Loiodice A, et al. SARS-CoV-2 detection in the lower respiratory tract of invasively ventilated ARDS patients. Crit Care. 2020;24:1-6.

6. Mehta P, McAuley DF, Brown M, Sanchez E, Tattersall RS, Manson JJ, et al. COVID-19: consider cytokine storm syndromes and immunosuppression. Lancet. 2020;395:1033-4.

\section{Publisher's Note}

Springer Nature remains neutral with regard to jurisdictional claims in published maps and institutional affiliations.
Ready to submit your research? Choose BMC and benefit from:

- fast, convenient online submission

- thorough peer review by experienced researchers in your field

- rapid publication on acceptance

- support for research data, including large and complex data types

- gold Open Access which fosters wider collaboration and increased citations

- maximum visibility for your research: over 100M website views per year

At BMC, research is always in progress.

Learn more biomedcentral.com/submissions 